\title{
Infantile choroidocerebral calcification syndrome
}

INSERM

\section{Source}

INSERM. (1999). Orphanet: an online rare disease and orphan drug data base. Infantile choroidocerebral calcification syndrome. ORPHA:1313

This syndrome is characterized by intellectual deficit, calcification of the choroid plexus, and elevated levels of cerebrospinal fluid (CSF) protein. It has been described in two sibships from two unrelated families. The seven children of one of the sibships were born to consanguineous parents. Some patients also had strabismus, hyperactive deep tendon reflexes and foot deformities. 